\title{
Multiple Criteria Decision Analysis Using DEA-TOPSIS METHOD FOR HAZARDOUS WASTE MANAgement: A CASE STUdy OF THE USA
}

\author{
Mohsin $\mathrm{Ali}^{1{ }^{1 *}}$, Amit Yadav ${ }^{1}$, Maira Anis ${ }^{1}$ and Pooja Sharma ${ }^{2}$ \\ ${ }^{1} \mathrm{PhD}$ Scholar, School of Management Science and Economics, \\ University of Electronic Science and Technology of China. \\ ${ }^{2}$ Wichita State University, Wichita, Kansas, USA.
}

\begin{abstract}
Environmental pollution is one of the major concerns in the recent world. Hazardous waste is the major factors causing pollution and degradation of environment. It is such waste with a chemical composition or other properties that make it capable of causing harm to humans and other life forms when mishandled or released into the environment. USA (United State of America)is developed country but facing tough time to secure the life from hazardous waste. Dealing with such problem is not easy task for the hazardous waste management officers because all parties have their own opinion and views which is difficult to put all together at once. Even it is tough task to gratify all concern parties but researcher always try to come up with new proposal so that can be beneficial for the present improvement and future decision making. This paper adopts MCDA (multiple criteria decision analysis) for analysis of hazardous waste in the USA. MCDA proposed DEA-TOPSIS (data envelopment analysis - technique for order performance by similarity to ideal solution) hybrid approach for findings of hazardous waste. MCDA helps in solving decision making problems in various sectors such as corporate, social and environmental issues. This paper will help EPA (environmental protection agency) to improve hazardous waste in different states while comparing with the best one.
\end{abstract}

KEYWORDS: Hazardous Waste, MCDA, DEA-TOPSIS, EPA, USA

\section{INTRODUCTION}

Hazardous waste is a major problem causing environmental pollution and illness to life forms. Developing a regulatory program as well as improvement proposal that ensures the safe handling of such dangerous waste is required for healthy environment. Industrial waste, hospitals, timber treatment, petrol storage, metal finishing, chemical and toxic substances etc. are the different sources of hazardous waste. There are different ways of treating those waste such as chemically treated (neutralization, oxidation, reduction, hydrolysis, precipitation), biologically (using microorganisms) or thermal (incineration) and physically (encapsulation, separation). So, waste analysis implies identification and verification of the chemical and physical properties of waste. This identification is done either by testing or in certain situation by applying knowledge of the waste. Industrial, commercial and agricultural sites were decently managed, stored, transported or disposed then there would be no environmental pollution and no need to execute any site remediation. The goal of this study is also to find out which state of USA is well managed and 
International Journal of Managing Information Technology (IJMIT) Vol.7, No.3, August 2015

which needs to take in consideration for well managed hazardous waste. As being a developed country, most of people might think that the USA is well managed and secure place to live in healthy environment but developed country produce much hazardous waste than any other. The manufacturing of products for domestic consumption or further industrial application produces most hazardous wastes. Ng (2001) and Chui (2003) conducted lot of projects in waste but many of them fail to achieve their goals, bring forth environmental and social problems in the community. Therefore, promoting sustainability concept the respective authorities and the related parties endeavor to improve the design of the proposal (Fung 2001). Developing world and competitive strategy makes rapid development as well as improvement of various industrial technologies, products and practices frequently increase the generation rate of hazardous waste.

The hazardous waste data and its information collected by EPA. They obtain information on the chemical and physical properties needed to effectively treated, stored or disposed of the waste in accordance with permit, process or regulatory. There are many treatment facilities in each state of each region and those treatment facilities will have information needs to ensure safe and effective treatment. Yet there are many states of USA that have not managed hazardous waste well. This research will help to know that state condition towards hazardous waste management and state need to take in consideration for better management. To know hazardous waste in USA some variables such as waste generated, waste received and managed, waste shipped offsite, received for transfer storage, population density and number of facilities data's were collected from EPA. In order to ensure that the final result of analysis is winning over, we followed two methodologies that are DEA and TOPSIS. In deciding on the best methods for managing and dealing with decision making challenges in hazardous waste MCDA is followed.

\section{LITERATURE REVIEW}

Multiple criteria decision analysis (MCDA) helps in decision making process and helps decision makers in complex decision situation involving multiple criteria arising from economic, social and environmental consideration (Figueira et al.2005, Hwang \& Yoon 1981, Keeney \& Raiffa 1976, Saaty 1980). The main idea of MCDA is to concentrates on decision analysis within a finite set of alternatives and offers technique to help decision makers in making decisions. It purposes two unique features for handling decision problems i.e. preference-based aggregation and ability to handle both quantitative and qualitative criteria (Chen 2009). Three MCDA fundamental problems are proposed for evaluating a set of alternatives i.e. choice, sorting and ranking (Roy 1996). Various researchers proposed different approaches on MCDA such as multi-attributes utility theory (MAUT) (Kaaney\&Raiffa 1976), outranking methods (Roy 1996), and analytical hierarchy process (AHP) (Saaty 1980). A state of the art review of MCDA and summarizing many MCDA approaches catered for different decision scenarios by Figueria et al. (2005).

For solving multi-objective decision problems the popular method is TOPSIS (technique for order preference by similarity to ideal solution) is used (Chu 2007, Tsou 2007, Wang \& Chang 2007, Yurdakul 2005, Hwang 1981). For TOPSIS in group decision making, the common approaches in aggregating individual decision makers' judgments are the geometric or the arithmetic mean methods. These are visceral and do not consider either preference levels or preference priorities among alternatives for individual decision makers. TOPSIS is different from other MCDM methods because it depends on logical thinking and which is based on simultaneous evaluation of the nearest distance from the best alternative (positive ideal solution; FPIS) and the longest distance from the worse alternative (negative ideal solution; FNIS). TOPSIS is a straight forward 
technique and suitable for cases with a large number of attributes and alternatives, it is especially appropriate for use with objective or quantitative data (Shih et al. 2007). TOPSIS have been widely used in various sectors such as transportation (Janic 2003), financial events (Deng et al. 2000), product design (Lin et al. 2008a,b), facility location (Chu 2002), consumer satisfaction (Lin \& Chang 2008), service quality (Tsaur et al. 2002) and personal decisions (Chen \&Tzeng 2004). This paper is motivated to focus on DEA-TOPSIS with intent to decision making on hazardous waste condition in the USA, andthe result deal with problems regarding hazardous waste.

Charnes (1978) originated the Data envelopment analysis (DEA) and initial DEA model was named CCR (Charnes, Cooper and Rhodes) model. Linear programming based technique is DEA, which helps in measuring relative efficiency of a fairly homogeneous set of decision making units (DMUs) and their use of multiple inputs to produce multiple outputs. Various researches have been conducted on DEA from last thirty years (1978-2008) for both theoretical extensions and practical applications, including various DEA-based MCDA approaches (Emrouznejad 2008). The attempts of combining DEA with MCDA, researcher found out the utilization of crossefficiency analysis in DEA for evaluating alternatives in MCDA and also suggest that cross efficiency based DEA analysis could be Multi-attribute Choice (tool) for the Lazy Decision Maker. DEA arises from situations where the goal is to determine the productive efficiency of a system by comparing how well the system converts inputs into outputs, while MCDA models have come up with analyze a set of alternatives according to conflict criteria (Stewart 1996). Various methods have been developed for MCDA by bringing more preference information into the DEA like model, such as modified DEA approach yield result very similar to those produced using SMART (simple multi attribute rating technique) (Seydel 2006), DEA based MCDA method to handle both cardinal and ordinal criteria (Cook \& Kress 1994), DEA based index aggregation model has been developed for aggregating different country ranking indices (Chen\&Hipel 2009), different DEA based methods are proposed for weight derivation and aggregation in the AHP (Ramanathan 2006, Wang \& Chin 2009). Hybrid approach to MCDA that capitalizes on the unique features of DEA and TOPSIS are put forward such as a convenient way for determining criterion weight in TOPSIS, a theoretically sound approach to qualitative criterion quantification in TOPSIS (Chen 2009).

This paper is organized as follows: overviews of Hazardous waste are given in section 1, section 2 explains about the past work on MCDA and DEA-TOPSIS, methodology followed for analysis of hazardous waste is mentioned in section 3, section 4 shows data analysis results, result explanation and conclusion is detailed in section 5 .

\section{METHODOLOGY}

The basic structure of an MCDA problem is illustrated by Chen et al (2006) in his paper and which contains the main components such as alternatives set is given as $A=\left(a^{1}, a^{2}, \ldots, a^{n}\right)$ and criteria set $\mathrm{C}=\left(\mathrm{c}^{1}, \mathrm{c}^{2}, \ldots, \mathrm{c}^{\mathrm{q}}\right)$, direct physical measurement as the aftermath of alternative $\mathrm{a}^{\mathrm{i}}$ on criteria $c^{j}$ for all $i=1, \ldots, n$ and $j=1, \ldots, q$, which is denoted by $m_{j}^{i}$ and $(i, j)$ represent entry of an $\mathrm{n} \times \mathrm{q}$ matrix know as information matrix. DM's preferences to solve any MCDA problem and these preference expressions have been mentioned by Chen et al. (2009).

Distance based approach is TOPSIS method and its general procedure consist of construction of a performance matrix, normalize performance matrix, defined the ideal and anti-ideal point, assign 
weight to criteria, calculate distances of $\mathrm{a}^{\mathrm{i}}$ to the two ideal points which is $\mathrm{a}^{+}$and $\mathrm{a}^{-}$, obtaining an integrated distance $\mathrm{a}^{\mathrm{i}}$ to these two extreme points (Shih 2007).

Here, vector normalization $\left(\mathrm{v}_{\mathrm{j}}^{\mathrm{i}}\right), v_{j}^{i}=\frac{m_{j}^{i}}{\sqrt{\sum_{i=1}^{n}\left(m_{j}^{i}\right)^{2}}}$; where, $\mathrm{m}_{\mathrm{j}}^{\mathrm{i}}=$ mapping to $0 \leq \mathrm{v}_{\mathrm{j}}^{\mathrm{i}} \leq 1$.

Sum based linear normalization $\left(\mathrm{v}_{\mathrm{j}}^{\mathrm{i}}\right), v_{j}^{i}=\frac{m_{j}^{i}}{\sum_{i=1}^{n}\left(m_{j}^{i}\right)}$

Min-max-based normalization $\left(\mathrm{v}_{\mathrm{j}}^{\mathrm{i}}\right), v_{j}^{i}=\frac{m_{j}^{i}}{\max _{i=1}^{n} m_{j}^{i}}\left(\mathrm{C}_{\mathrm{j}}\right.$ is a cost benefit criterion $)$ and $v_{j}^{i}=\frac{\min _{i=1}^{n} m_{j}^{i}}{m_{j}^{i}}\left(\mathrm{C}_{\mathrm{j}}\right.$ is a cost criterion $)$

For ideal and anti-ideal point, for benefit criterion cj, $v_{j}\left(a^{+}\right)=\max _{i=1}^{n} v_{j}^{i}$ and $v_{j}\left(a^{-}\right)=\min _{i=1}^{n} v_{j}^{i}$, and for cost criterion $\mathrm{C}_{\mathrm{k}}, v_{j}\left(a^{+}\right)=\min _{i=1}^{n} v_{j}^{i}$ and $v_{j}\left(a^{-}\right)=\max _{i=1}^{n} v_{j}^{i}$

Assign weights to criteria: Set $w_{j}\left(w_{j} \in R_{\&}^{+} \sum_{j=1}^{q} w_{j}=1\right)$ to represent the relative importance of criteria, $\mathrm{C}_{\mathrm{j}}$.

To calculate distance of ai to two (a+ \& a-) ideal point,

$D\left(a^{i}\right)^{+}=\left\{\sum_{j=1}^{q} w_{j}\left|v_{j}\left(a^{+}\right)-v_{j}\left(a^{i}\right)\right|^{p}\right\}^{\frac{1}{p}}$ and $D\left(a^{i}\right)^{-}=\left\{\sum_{j=1}^{q} w_{j}\left|v_{j}\left(a^{i}\right)-v_{j}\left(a^{-}\right)\right|^{p}\right\}^{\frac{1}{p}}$

Where, $\mathrm{p}$ is a pre-defined distance norm and it is set as 1 or 2 . $|\mathrm{x}|$ represent the absolute value of $\mathrm{x}$.

To obtain integrated distance $\left(\mathrm{a}^{\mathrm{i}}\right), D\left(a^{i}\right)=\frac{D\left(a^{i}\right)^{-}}{D\left(a^{i}\right)^{-}+D\left(a^{i}\right)^{+}}$, Maximum value of $\mathrm{D}\left(\mathrm{a}^{\mathrm{i}}\right)$ represent better overall performance.

Chen et al. (2009) have explained DEA-TOPSIS method and mention steps to be followed such as flexible setting of $\mathrm{a}^{+}$and $\mathrm{a}^{-}$, distance definitions and aggregation over $\mathrm{C}^{\mathrm{c}}$, distance definitions and aggregation over $\mathrm{C}^{\mathrm{o}}$, imprecise intrinsic preference expressions (e.g. weak ranking, strict ranking, difference ranking and fixed bounds ) and DEA based optimization models. Unique feature of new distance the following normalization functions can be applied to any kind of criterion, cost, non-monotonic and benefit, which is mention in eq. 1-6 below. 
Vector based normalization,

$$
\mathcal{E}_{j}^{+}=\sqrt{\sum_{i=1}^{n}\left(m_{j}^{c}\left(a^{+}\right)-m_{j}^{c}\left(a^{i}\right)\right)^{2}+\left(m_{j}^{c}\left(a^{+}\right)-m_{j}^{c}\left(a^{-}\right)\right)^{2}}
$$

(Ideal normalization factor)

$$
\varepsilon_{j}^{-}=\sqrt{\sum_{i=1}^{n}\left(m_{j}^{c}\left(a^{-}\right)-m_{j}^{c}\left(a^{i}\right)\right)^{2}+\left(m_{j}^{c}\left(a^{-}\right)-m_{j}^{c}\left(a^{-}\right)\right)^{2}}
$$

(Anti-ideal normalization factor).

Where, $\mathrm{m}_{\mathrm{j}}^{\mathrm{c}}\left(\mathrm{a}^{\mathrm{i}}\right)=$ consequence measurement of $\mathrm{a}^{\mathrm{i}}$ on a quantitative criterion, $\mathrm{C}_{\mathrm{j}}^{\mathrm{c}}$.

Sum-based absolute normalization,

$$
\begin{aligned}
& \varepsilon_{j}^{+}=\sum_{i=1}^{n}\left|m_{j}^{c}\left(a^{+}\right)-m_{j}^{c}\left(a^{i}\right)\right|+\left|m_{j}^{c}\left(a^{+}\right)-m_{j}^{c}\left(a^{-}\right)\right| \\
& \varepsilon_{j}^{-}=\sum_{i=1}^{n}\left|m_{j}^{c}\left(a^{-}\right)-m_{j}^{c}\left(a^{i}\right)\right|+\left|m_{j}^{c}\left(a^{-}\right)-m_{j}^{c}\left(a^{+}\right)\right|
\end{aligned}
$$

Max-based absolute normalization,

$$
\begin{array}{lll}
\mathcal{E}_{j}^{+}=\max \left\{\max _{i=1}^{n}\left|m_{j}^{c}\left(a^{+}\right)-m_{j}^{c}\left(a^{i}\right)\right|,\left|m_{j}^{c}\left(a^{+}\right)-m_{j}^{c}\left(a^{-}\right)\right|\right\} & \ldots & \mathrm{eq}(5) \\
\mathcal{E}_{j}^{-}=\max \left\{\max _{i=1}^{n}\left|m_{j}^{c}\left(a^{-}\right)-m_{j}^{c}\left(a^{i}\right)\right|,\left|m_{j}^{c}\left(a^{+}\right)-m_{j}^{c}\left(a^{-}\right)\right|\right\} & \ldots & \mathrm{eq}(6)
\end{array}
$$

Distance definitions and aggregation over $\mathrm{C}^{\mathrm{o}}$, where linguistic grade evaluations are commonly employed for measuring consequences over qualitative criteria $\mathrm{C}^{0}$. Then weighted p-power distance of $\mathrm{a}^{\mathrm{i}}$ to $\mathrm{a}^{+}$over $\mathrm{C}^{\mathrm{c}}$ and $\mathrm{C}^{\mathrm{o}}$ is given below:

$D\left(a^{i}\right)^{+}=\left\{\sum_{j=1}^{q} w_{j}^{c} \cdot\left(d_{j}^{c}\left(a^{i}\right)^{+}\right)^{p}+\sum_{j=1}^{q} w_{j}^{o} \cdot\left(d_{j}^{o}\left(a^{i}\right)^{+}\right)^{p}\right\}^{\frac{1}{p}}$ And $D\left(a^{i}\right)^{-}=\left\{\sum_{j=1}^{q} w_{j}^{c} \cdot\left(d_{j}^{c}\left(d^{i}\right)^{-}\right)^{p}+\sum_{j=1}^{q} w_{j}^{o} \cdot\left(d_{j}^{o}\left(a^{i}\right)^{-}\right)^{p}\right\}^{\frac{1}{p}}$

where, $\mathrm{w}^{\mathrm{c}}=\left(\mathrm{w}_{1}^{\mathrm{c}}, \ldots, \mathrm{w}_{\mathrm{j}}^{\mathrm{c}}, \ldots, w_{q_{c}}^{\mathrm{c}}\right)$ (weight information for $\left.\mathrm{C}^{\mathrm{c}}\right)$ and $\mathrm{w}^{\mathrm{o}}=\left(\mathrm{w}_{1}^{\mathrm{o}}, \ldots, \mathrm{w}_{\mathrm{j}}^{\mathrm{o}}, \ldots, w_{q_{o}}^{c}\right)$ (weight information for $\mathrm{C}^{\mathrm{o}}$ ).

When, $a^{i}=q^{-}, D\left(a^{i}\right)^{+}=D\left(a^{-}\right)^{+}$and $D\left(a^{i}\right)^{-}=D\left(a^{+}\right)^{-}$for $a^{i}=a^{+}$.

DEA based optimization model is used to get the analysis for above mentioned problems. This model is designed to tackle some task such as individual optimization models, integrated optimization model. The final aggregation procedure in the TOPSIS method, the total distance 
performance of $\mathrm{a}^{\mathrm{i}}, \mathrm{D}\left(\mathrm{a}^{\mathrm{i}}\right)$ can be calculated as mention in eq. 7 (where, $\mathrm{P}\left(\mathrm{a}^{\mathrm{i}}\right)^{+}$and minimize $\mathrm{D}\left(\mathrm{a}^{\mathrm{i}}\right)^{+}$). For an integrated optimization model for two distance measurements from $\mathrm{a}^{+}$and $\mathrm{a}^{-}$is mentioned in eq. 7 (where, $\mathrm{P}\left(\mathrm{a}^{\mathrm{i}}\right)$ and maximize).

$$
D\left(a^{i}\right)=\frac{D\left(a^{i}\right)^{-}}{D\left(a^{i}\right)^{-}+D\left(a^{i}\right)^{+}} \quad \ldots \quad \operatorname{eq}(7)
$$

The above steps have been followed for the analysis of hazardous waste of the USA and these steps have detailed mention by Chen et al. (2009).

\section{DATA ANALYSIS}

Hazardous waste is one of the major problems for the developed country like the USA. As much country move towards development, hazardous waste also increases such as from industry, manufacturing products, chemical used and so on. A waste is considered hazardous when it poses a threat to human health or environment, according to the USA Resource Conservation and Recovery Act (RCRA) of 1978. From past twenty five years, government, industry and the industry general public had been developed as well as developing countries have become increasingly aware of the need to act on hazardous waste problems. Keeping those things in mind, we have collected data of hazardous waste from RTKNet (Right To Know Network) and found out the condition of hazardous waste of various states of the USA using DEA-TOPSIS methodology. It is impossible for all parties to be satisfied on hazardous waste result because there are various variables need to take in consideration on data analysis and different variables analysis give different result. But in this paper we try to take data of waste generated, waste received and managed, waste shipped offsite, waste received for transfer and storage, population density of each states and number of facilities in each states.

\section{Alternative and criterion Identification:-}

To render a comprehensive evaluation of hazardous waste, two additional criteria population density of each state and number of facilities calibrates analysis of hazardous waste. In parallel to the basic structure of an MCDA problem demonstrated the 50 states of USA constitute the alternative set A, labeled as a - a50. The six criteria mentioned below establish the criterion set $\mathrm{C}$ and the first five are generally measures on a quantitative basis and last number of facilities has been evaluated in a subjective basis. In Table 1, first five criteria are treated as quantitative criteria $(\mathrm{Cc})$ and labeled as $\mathrm{Cc} 1-\mathrm{Cc} 5$ in the same ordered as the column in Table 1 and the last criterion (number of facilities) is given as qualitative criterion, labeled as Co6. 
International Journal of Managing Information Technology (IJMIT) Vol.7, No.3, August 2015

Table 1: Basic Structure of the problem

\begin{tabular}{|c|c|c|c|c|c|c|}
\hline \multirow[b]{2}{*}{ Alternative } & \multicolumn{6}{|c|}{ Criteria } \\
\hline & $\begin{array}{c}c_{1}^{c} \\
\text { Waste } \\
\text { Generate } \\
\text { d(Tous) }\end{array}$ & $\begin{array}{c}c_{2}^{s} \\
\text { Received } \\
\& \\
\text { Managed } \\
\text { (Tour) }\end{array}$ & $\begin{array}{l}c_{i}^{z} \\
\text { Shipped } \\
\text { Offite } \\
\text { (Toms) }\end{array}$ & $\begin{array}{c}c_{d}^{c} \\
\text { Received for } \\
\text { Tramefer } \\
\text { Storage (Tom) }\end{array}$ & $\begin{array}{c}c_{s}^{c} \\
\text { Population } \\
\text { Demity }\end{array}$ & $\begin{array}{c}C_{G}^{0} \\
\text { Number of } \\
\text { Facilities }\end{array}$ \\
\hline$a^{1}$ (Alasks) & 2523 & 12 & 2009 & 5 & 12 & Ll \\
\hline$a^{2}$ (Csabformia) & 561105 & 136700 & 4285557 & 46391 & 239.1 & L4 \\
\hline$a^{2}$ (Colorado) & 31900 & 40219 & 34643 & 3621 & 455 & $\mathrm{Ll}$ \\
\hline$a^{d}$ (Haxsii) & 423609 & 139 & 1301 & 51 & 211.3 & Ll \\
\hline$a^{5}$ (Idabo) & 3742 & 112054 & 6353 & 194 & 19.0 & $\mathrm{Ll}$ \\
\hline$a^{6}$ (Montana) & 5853 & 5 & 5956 & 4 & 63 & $\mathrm{Ll}$ \\
\hline$a^{7}$ (Nevada) & 12309 & 76324 & 11928 & 2427 & 24.6 & $\mathrm{Ll}$ \\
\hline$a^{i}$ (Oreqon) & 93525 & 54642 & 77390 & 532 & 399 & LI \\
\hline$a^{9}$ (Utah) & 49831 & 135537 & 79516 & 10068 & 35.6 & $\mathrm{Ll}$ \\
\hline$a^{10}$ (Wushington) & 349564 & 15935 & 75735 & 36068 & 95563 & $\mathrm{~L} 2$ \\
\hline$d^{11}$ (Wyoming) & 4079 & 5 & 4078 & 6 & 3.5 & $\mathrm{Ll}$ \\
\hline$a^{12}$ (Arinona) & 202987 & 13051 & 26498 & 4533 & 563 & L.2 \\
\hline$a^{12}$ (New Merico) & 1037437 & 4227 & 10357 & 510 & 17.0 & $\mathrm{Ll}$ \\
\hline$a^{14}$ (Oklaboma) & 44783 & 93288 & 29979 & 999 & 34.7 & L/2 \\
\hline$a^{1 s}$ (Texas) & 15683408 & 613952 & 607323 & 39663 & 963 & L4 \\
\hline$a^{16}$ (Illinois) & 696911 & 369526 & 207890 & 11344 & 2311 & L4 \\
\hline$a^{17}$ (Indiana) & $\mathbf{3 5 9 0 6 2}$ & 452403 & 399390 & 10662 & $1810^{\circ}$ & L3 \\
\hline$a^{15}$ (Kamsas) & 51008 & 267 & 50698 & 303 & 343 & Ll \\
\hline$a^{19}$ (Lotra) & 4399787 & 462718 & 516502 & 23542 & 1049 & $\mathrm{~L} 2$ \\
\hline$d^{20}$ (Michigan) & 318617 & 422990 & 177234 & 20798 & 174.8 & L2 \\
\hline$a^{2}$ (Mindesota) & 354706 & 165633 & 70561 & 3450 & 66.6 & $\mathrm{~L} 2$ \\
\hline$a^{2}$ (Missouri) & 253941 & 149297 & 31411 & 3090 & 37.1 & $\mathrm{~L} 2$ \\
\hline$a^{Z}$ (Nebraska) & 35438 & 33716 & 43668 & 3714 & 235 & $\mathrm{Ll}$ \\
\hline$d^{A}$ (North Dakota) & 455967 & 102 & 1178 & 193 & 9.7 & Ll \\
\hline$a^{2}$ (Olio) & 1617571 & 583683 & 565414 & 37391 & 2323 & $\mathrm{~L} 3$ \\
\hline$a^{26}$ (South Dakota) & 1344 & 2 & 1390 & 102 & 107 & $\mathrm{Ll}$ \\
\hline$a^{27}$ (Wïcomin) & 239401 & 44004 & 173035 & 8348 & 10050 & $\mathrm{~L} 3$ \\
\hline$a^{2 i}$ (Alabsma) & 595903 & 234002 & 191994 & 12211 & 94.4 & L/2 \\
\hline$d^{2}$ (Arkamas) & 991143 & 233161 & 205635 & 7436 & 560 & $\mathrm{Ll}$ \\
\hline$a^{20}$ (Florida) & 203410 & 551 & 33514 & 10229 & 3506 & $\mathrm{~L} 2$ \\
\hline$d^{n}$ (Georgia) & 211462 & 2615 & 42260 & 1247 & 1653.4 & $\mathrm{~L}_{2}$ \\
\hline$d^{22}$ (Kentockv) & 1245285 & 261193 & 135493 & 1056 & 349 & L/2 \\
\hline
\end{tabular}




\begin{tabular}{|c|c|c|c|c|c|c|}
\hline$d^{27}$ (Louinians) & 209464 & 39505 & 181969 & 16552 & 1099 & L2 \\
\hline$d^{2 / 4}$ (Missicsipi) & 1825969 & 17890 & 73094 & 46 & 652 & Ll \\
\hline$d^{2 s}$ (North Caroh) & 83317 & 3852 & 90479 & 3424 & 1961 & L3 \\
\hline$d^{76}$ (South Carol) & 177294 & 150194 & 171165 & 4429 & 1539 & L2 \\
\hline$a^{77}$ (Temenses) & 90133 & 22530 & 52837 & 6324 & 1539 & L.2 \\
\hline$d^{31}$ (Virginia) & 74531 & 7 & 71644 & 535 & 20026 & L2 \\
\hline$d^{30}$ (West Virgin) & 62539 & 5940 & 39475 & 456 & $7 T$ & Ll \\
\hline$a^{s 0}$ (Counecticut) & 25010 & 6441 & 24073 & 2385 & 735.1 & L2 \\
\hline$a^{a}$ (Delawgre) & 43257 & 114 & 42972 & 3 & 4605 & LI \\
\hline$a^{E}$ (Maine) & 2495 & 3 & 2326 & 139 & 45.1 & LI \\
\hline$a^{e}$ (Maryland) & 44254 & 43578 & 54571 & 12594 & 594.3 & Ll \\
\hline$a^{S t}$ (Massachuetts) & 36915 & 2303 & 42057 & 6614 & 339.4 & L2 \\
\hline$a^{E S}$ (New Hamphire) & 3950 & 3 & 3950 & 2 & 1470 & Ll \\
\hline$a^{E S}$ (New Jersey) & 297706 & 227285 & 328125 & 15113 & 11953 & $\mathrm{~L} .3$ \\
\hline$a^{g}$ (New York) & 186456 & 74567 & 165902 & 3542 & 4112 & $\mathrm{~L} 4$ \\
\hline$a^{a t}$ (Pennyhrsii) & 321891 & 394524 & 262670 & 43850 & 2839 & $\mathrm{~L} 3$ \\
\hline$a^{a}$ (Rbode Irland) & 8597 & 4019 & 16222 & 5958 & I015.1 & LI \\
\hline$d^{50}$ (Vermont) & 2813 & 10 & 2591 & 1506 & 679 & Ll \\
\hline$A+($ Ideal $)$ & 1344 & 613952 & 607323 & 46391 & 98565 & LI \\
\hline A- (Anti-ides $)$ & 15693409 & 2 & 1178 & 2 & 12 & $\mathrm{~L} 4$ \\
\hline
\end{tabular}

Table 1 explains the values of different variables and these values have been taken from RTKNet. It is believe that those variables are the major factors which cause hazardous waste problems. Population density is derived from formula: total number of people in the state/ total area of the state in $\mathrm{km}$ (kilometers).

\section{Hazardous Waste Facilities Estimate:}

The procedure to estimate hazardous waste facilities of each 50 states of the USA is explained (the result is listed in the Table 1). The numbers of facilities have given the linguistic (L) number in Table 2 as mention below:

If number of facility $<200$, then belongs to L1, If $200<=$ number of Facility $<500$, then belongs to L2, If $500<=$ Numbr of Facility $<1000$, then belongs to L3, If number of facility $>=1000$, then belongs to L4. 
Table 2: Basic Structure of the problem

\begin{tabular}{|c|c|c|}
\hline Alternative & $\begin{array}{c}\text { Number } \\
\text { of } \\
\text { Facilitie } \\
\text { s } \\
\end{array}$ & $\begin{array}{c}\text { Linguis } \\
\text { tic } \\
\text { Grade }\end{array}$ \\
\hline$a^{1}$ (Alaska) & 46 & L1 \\
\hline$a^{2}$ (California) & 1269 & $\mathrm{~L} 4$ \\
\hline$a^{3}($ Colorado $)$ & 158 & L1 \\
\hline$a^{4}$ (Hawaii) & 51 & L1 \\
\hline$a^{5}$ (Idaho) & 40 & L1 \\
\hline$a^{6}$ (Montana) & 45 & L1 \\
\hline$a^{7}$ (Nevada) & 102 & L1 \\
\hline$a^{8}$ (Oregon) & 181 & L1 \\
\hline$a^{9}$ (Utah) & 113 & L1 \\
\hline$a^{10}$ (Washington) & 420 & $\mathrm{~L} 2$ \\
\hline$a^{11}$ (Wyoming) & 19 & L1 \\
\hline$a^{12}$ (Arizona) & 229 & $\mathrm{~L} 2$ \\
\hline$a^{13}$ (New Mexico) & 46 & L1 \\
\hline$a^{14}$ (Oklahoma) & 203 & $\mathrm{~L} 2$ \\
\hline$a^{15}$ (Texas) & 1020 & $\mathrm{~L} 4$ \\
\hline$a^{16}$ (Illinois) & 1123 & $\mathrm{~L} 4$ \\
\hline$a^{17}$ (Indiana) & 517 & L3 \\
\hline$a^{18}$ (Kansas) & 161 & L1 \\
\hline$a^{19}$ (Lowa) & 371 & $\mathrm{~L} 2$ \\
\hline$a^{20}$ (Michigan) & 490 & L2 \\
\hline$a^{21}$ (Minnesota) & 324 & $\mathrm{~L} 2$ \\
\hline$a^{22}$ (Missouri) & 343 & $\mathrm{~L} 2$ \\
\hline$a^{23}$ (Nebraska) & 84 & L1 \\
\hline $\begin{array}{l}a^{24} \text { (North } \\
\text { Dakota) }\end{array}$ & 19 & L1 \\
\hline$a^{25}$ (Ohio) & 917 & L3 \\
\hline
\end{tabular}

\begin{tabular}{|c|c|c|}
\hline $\begin{array}{l}a^{26}(\text { South } \\
\text { Dakota })\end{array}$ & 42 & L1 \\
\hline$a^{27}$ (Wisconsin) & 541 & L3 \\
\hline$a^{28}$ (Alabama) & 245 & L2 \\
\hline$a^{29}$ (Arkansas) & 144 & L1 \\
\hline$a^{30}$ (Florida) & 451 & L2 \\
\hline$a^{31}$ (Georgia) & 389 & L2 \\
\hline$a^{32}$ (Kentucky) & 220 & L2 \\
\hline$a^{33}$ (Louisiana) & 274 & L2 \\
\hline$a^{34}$ (Mississippi) & 132 & L1 \\
\hline$a^{35}$ (North Caroli) & 608 & L3 \\
\hline$a^{36}$ (South Carol) & 290 & L2 \\
\hline$a^{37}$ (Tennessee) & 336 & L2 \\
\hline$a^{38}$ (Virginia) & 391 & L2 \\
\hline$a^{39}$ (West Virgin) & 143 & L1 \\
\hline$a^{40}$ (Connecticut) & 297 & L2 \\
\hline$a^{41}$ (Delaware) & 59 & L1 \\
\hline$a^{42}$ (Maine) & 66 & L1 \\
\hline$a^{43}$ (Maryland) & 134 & L1 \\
\hline $\begin{array}{l}a^{44} \\
\text { (Massachusetts) }\end{array}$ & 450 & L2 \\
\hline $\begin{array}{l}a^{45} \text { (New } \\
\text { Hampshire) }\end{array}$ & 152 & L1 \\
\hline$a^{46}$ (New Jersey) & 689 & L3 \\
\hline$a^{47}$ (New York) & 1476 & L4 \\
\hline$a^{48}$ (Pennsylvani) & 853 & L3 \\
\hline $\begin{array}{l}a^{49} \text { (Rhode } \\
\text { Island) }\end{array}$ & 93 & L1 \\
\hline$a^{50}$ (Vermont) & 52 & L1 \\
\hline
\end{tabular}

\section{Ideal and Anti-ideal Setting:}

It is assumed that all quantitative criteria $\left(\mathrm{C}_{1}^{\mathrm{c}}-\mathrm{C}_{5}^{\mathrm{c}}\right)$, whose larger values receives greater attention of hazardous waste management. Then $\mathrm{a}^{+}$and $\mathrm{a}^{-}: \forall c^{c}{ }_{j} \in c^{c}$, generate min-max setting. Where, $\mathrm{m}_{\mathrm{j}}^{\mathrm{c}}\left(\mathrm{a}^{+}\right)=\max ^{50}{ }_{\mathrm{i}-1} \mathrm{~m}_{\mathrm{j}}^{\mathrm{c}}\left(\mathrm{a}^{\mathrm{i}}\right)$ and $\mathrm{m}_{\mathrm{j}}^{\mathrm{c}}\left(\mathrm{a}^{-}\right)=\max ^{50}{ }_{\mathrm{i}=1} \mathrm{~m}_{\mathrm{j}}^{\mathrm{c}}\left(\mathrm{a}^{\mathrm{i}}\right)$. For qualitative criterion $\forall c^{c}{ }_{1}$, $\mathrm{m}_{1}^{\mathrm{o}}\left(\mathrm{a}^{+}\right)=\mathrm{L}_{1}$ and $\mathrm{m}_{1}^{\mathrm{o}}\left(\mathrm{a}^{-}\right)=\mathrm{L}_{4}$. 


\section{DEA Based Optimization Analysis:}

In Table 3 and $4\left(\mathrm{a}^{+} \& \mathrm{a}^{-}\right)$the result of normalized distances is mentioned, whose normalized distance $\left(\mathrm{C}_{6}^{0}\right)$ values lies between $0-1$. Furthermore, assume that the intrinsic preference expressions are as follows:

a) The criteria waste generated $\left(\mathrm{C}_{1}^{\mathrm{c}}\right)$ preferred to the criteria waste received \& managed $\left(\mathrm{C}_{2}^{\mathrm{c}}\right)$ and $\mathrm{C}_{2}^{\mathrm{c}}$ is more important than the waste shipped offside.

$$
w_{1}^{c}>w_{2}^{c}>w_{3}^{c}
$$

b) The waste generated is preferred to the waste shipped off offside and the waste shipped off offside is more important than the waste sent for storage.

$$
w_{1}^{c}>w_{2}^{c}>w_{4}^{c}
$$

c) The hazardous waste received and manage is preferred than the waste sent for the storage.

$$
w_{2}^{c}>w_{4}^{c}
$$

d) The population density is preferred to the number of facilities.

$$
w_{5}^{c}>w_{6}^{o}
$$

The expression preferred or more important gives strength while assuming the weight gap between the above inequalities must be greater than or equal to 0.1 . Hence, above relationship can be translated as follows:
1) $w_{1}^{c} \geq w_{2}^{c}+0.1$
4) $w_{2}^{c} \geq w_{4}^{c}+0.1$
2) $w_{2}^{c} \geq w_{3}^{c}+0.1$
5) $w_{5}^{c} \geq w_{6}^{o}+0.1$;
3) $w_{1}^{c} \geq w_{4}^{c}+0.1$;

Then $P\left(a^{i}\right)^{+}$and $P\left(a^{i}\right)^{-}$are applied to find the optimal results of $D\left(a^{i}\right)^{+}$and $D\left(a^{i}\right)^{-}$ respectively. The brought forth optimal result for each alternative are aggregated as per $D\left(a^{i}\right)=\frac{D\left(a^{i}\right)^{-}}{D\left(a^{i}\right)^{-}+D\left(a^{i}\right)^{+}}$to find the final distance performance. These distances values and according to those values ranking are given in Table 5 . 
International Journal of Managing Information Technology (IJMIT) Vol.7, No.3, August 2015

Table 3: Normalized distance information to $a^{+}$

\begin{tabular}{|c|c|c|c|c|c|c|}
\hline \multirow{2}{*}{ Alternative } & \multicolumn{6}{|c|}{ Criteria } \\
\hline & $c_{1}^{c}$ & $c_{2}^{c}$ & $c_{3}^{c}$ & $c_{4}^{c}$ & $c_{5}^{c}$ & $c_{6}^{o}$ \\
\hline$a^{1}$ & 0.0000000006 & 0.0118 & 0.0016 & 0.0012 & 0.0502 & $0,0.25$ \\
\hline$a^{2}$ & 0.0001379780 & 0.0072 & 0.0001 & 0.0000 & 0.0478 & $0.75,1$ \\
\hline$a^{3}$ & 0.0000004112 & 0.0103 & 0.0015 & 0.0011 & 0.0497 & $0,0.25$ \\
\hline$a^{4}$ & 0.0000785190 & 0.0118 & 0.0016 & 0.0012 & 0.0480 & $0,0.25$ \\
\hline$a^{5}$ & 0.0000000025 & 0.0079 & 0.0016 & 0.0012 & 0.0500 & $0,0.25$ \\
\hline$a^{6}$ & 0.0000000091 & 0.0118 & 0.0016 & 0.0012 & 0.0501 & $0,0.25$ \\
\hline$a^{7}$ & 0.0000000529 & 0.0091 & 0.0016 & 0.0011 & 0.0499 & $0,0.25$ \\
\hline$a^{8}$ & 0.0000037419 & 0.0098 & 0.0012 & 0.0012 & 0.0498 & $0,0.25$ \\
\hline$a^{9}$ & 0.0000010353 & 0.0072 & 0.0012 & 0.0008 & 0.0498 & $0,0.25$ \\
\hline$a^{10}$ & 0.0000533964 & 0.0112 & 0.0013 & 0.0001 & 0.0000 & $0.25,0.5$ \\
\hline$a^{11}$ & 0.0000000033 & 0.0118 & 0.0016 & 0.0012 & 0.0501 & $0,0.25$ \\
\hline$a^{12}$ & 0.0000179049 & 0.0113 & 0.0015 & 0.0010 & 0.0496 & $0.25,0.5$ \\
\hline$a^{13}$ & 0.0004727179 & 0.0117 & 0.0016 & 0.0012 & 0.0500 & $0,0.25$ \\
\hline$a^{14}$ & 0.0000008309 & 0.0085 & 0.0015 & 0.0012 & 0.0496 & $0.25,0.5$ \\
\hline$a^{15}$ & 0.1082956230 & 0.0000 & 0.0000 & 0.0000 & 0.0492 & $0.75,1$ \\
\hline$a^{16}$ & 0.0002069686 & 0.0019 & 0.0007 & 0.0007 & 0.0479 & $0.75,1$ \\
\hline$a^{17}$ & 0.0003462387 & 0.0008 & 0.0002 & 0.0007 & 0.0483 & $0.5,0.75$ \\
\hline$a^{18}$ & 0.0000010862 & 0.0118 & 0.0014 & 0.0012 & 0.0496 & $0,0.25$ \\
\hline$a^{19}$ & 0.0085192707 & 0.0007 & 0.0000 & 0.0003 & 0.0491 & $0.25,0.5$ \\
\hline$a^{20}$ & 0.0000443273 & 0.0011 & 0.0008 & 0.0004 & 0.0484 & $0.25,0.5$ \\
\hline$a^{21}$ & 0.0000549850 & 0.0063 & 0.0013 & 0.0011 & 0.0495 & $0.25,0.5$ \\
\hline$a^{22}$ & 0.0000280971 & 0.0068 & 0.0012 & 0.0011 & 0.0493 & $0.25,0.5$ \\
\hline$a^{23}$ & 0.0000005119 & 0.0106 & 0.0014 & 0.0010 & 0.0499 & $0,0.25$ \\
\hline$a^{24}$ & 0.0000909738 & 0.0118 & 0.0016 & 0.0012 & 0.0501 & $0,0.25$ \\
\hline$a^{25}$ & 0.0011502951 & 0.0000 & 0.0000 & 0.0000 & 0.0473 & $0.5,0.75$ \\
\hline$a^{26}$ & 0.0000000000 & 0.0118 & 0.0016 & 0.0012 & 0.0501 & $0,0.25$ \\
\hline$a^{27}$ & 0.0000365394 & 0.0102 & 0.0008 & 0.0008 & 0.0491 & $0.5,0.75$ \\
\hline$a^{28}$ & 0.0001520224 & 0.0045 & 0.0008 & 0.0007 & 0.0492 & $0.25,0.5$ \\
\hline$a^{29}$ & 0.0004314184 & 0.0046 & 0.0007 & 0.0009 & 0.0496 & $0,0.25$ \\
\hline$a^{30}$ & 0.0000179801 & 0.0118 & 0.0015 & 0.0008 & 0.0467 & $0.25,0.5$ \\
\hline$a^{31}$ & 0.0000194416 & 0.0117 & 0.0014 & 0.0012 & 0.0485 & $0.25,0.5$ \\
\hline$a^{32}$ & 0.0006814031 & 0.0039 & 0.0010 & 0.0012 & 0.0498 & $0.25,0.5$ \\
\hline$a^{33}$ & 0.0000188908 & 0.0086 & 0.0008 & 0.0005 & 0.0491 & $0.25,0.5$ \\
\hline
\end{tabular}


International Journal of Managing Information Technology (IJMIT) Vol.7, No.3, August 2015

\begin{tabular}{|c|c|c|c|c|c|c|}
\hline$a^{34}$ & 0.0014708850 & 0.0112 & 0.0013 & 0.0012 & 0.0495 & $0,0.25$ \\
\hline$a^{35}$ & 0.0000029590 & 0.0117 & 0.0012 & 0.0008 & 0.0482 & $0.5,0.75$ \\
\hline$a^{36}$ & 0.0000136328 & 0.0068 & 0.0008 & 0.0010 & 0.0486 & $0.25,0.5$ \\
\hline$a^{37}$ & 0.0000034719 & 0.0110 & 0.0014 & 0.0009 & 0.0486 & $0.25,0.5$ \\
\hline$a^{38}$ & 0.0000023813 & 0.0118 & 0.0013 & 0.0012 & 0.0481 & $0.25,0.5$ \\
\hline$a^{39}$ & 0.0000016491 & 0.0116 & 0.0014 & 0.0012 & 0.0494 & $0,0.25$ \\
\hline$a^{40}$ & 0.0000002466 & 0.0116 & 0.0015 & 0.0011 & 0.0429 & $0.25,0.5$ \\
\hline$a^{41}$ & 0.0000007747 & 0.0118 & 0.0014 & 0.0012 & 0.0456 & $0,0.25$ \\
\hline$a^{42}$ & 0.0000000006 & 0.0118 & 0.0016 & 0.0012 & 0.0497 & $0,0.25$ \\
\hline$a^{43}$ & 0.0000008108 & 0.0102 & 0.0014 & 0.0007 & 0.0443 & $0,0.25$ \\
\hline$a^{44}$ & 0.0000005572 & 0.0117 & 0.0014 & 0.0009 & 0.0420 & $0.25,0.5$ \\
\hline$a^{45}$ & 0.0000000030 & 0.0118 & 0.0016 & 0.0012 & 0.0487 & $0,0.25$ \\
\hline$a^{46}$ & 0.0000386767 & 0.0047 & 0.0003 & 0.0006 & 0.0387 & $0.5,0.75$ \\
\hline$a^{47}$ & 0.0000150944 & 0.0091 & 0.0009 & 0.0008 & 0.0461 & $0.75,1$ \\
\hline$a^{48}$ & 0.0000452468 & 0.0017 & 0.0005 & 0.0000 & 0.0473 & $0.5,0.75$ \\
\hline$a^{49}$ & 0.0000000232 & 0.0117 & 0.0015 & 0.0009 & 0.0403 & $0,0.25$ \\
\hline$a^{50}$ & 0.0000000010 & 0.0118 & 0.0016 & 0.0012 & 0.0495 & $0,0.25$ \\
\hline$a^{-}$ & 0.1083 & 0.0118 & 0.0016 & 0.0012 & 0.0502 & 1 \\
\hline
\end{tabular}

Note: $z \in[x, y]$ " represent " $x \leq z \leq y$ ". 
International Journal of Managing Information Technology (IJMIT) Vol.7, No.3, August 2015

Table 4: Normalized distance information to $a^{-}$

\begin{tabular}{|c|c|c|c|c|c|c|}
\hline \multirow{2}{*}{ Alternative } & \multicolumn{6}{|c|}{ Criteria } \\
\hline & $c_{1}^{c}$ & $c_{2}^{c}$ & $c_{3}^{c}$ & $c_{4}^{c}$ & $c_{5}^{c}$ & $c_{6}^{o}$ \\
\hline$a^{1}$ & 0.1083 & 0.00000000 & 0.000000003 & 0.00000000 & 0.00000000 & $0.75,1$ \\
\hline$a^{2}$ & 0.1007 & 0.00058689 & 0.000808179 & 0.00123961 & 0.00002924 & $0,0.25$ \\
\hline$a^{3}$ & 0.1079 & 0.00005080 & 0.000004957 & 0.00000754 & 0.00000116 & $0.75,1$ \\
\hline$a^{4}$ & 0.1025 & 0.00000000 & 0.000000000 & 0.00000000 & 0.00002292 & $0.75,1$ \\
\hline$a^{5}$ & 0.1083 & 0.00039434 & 0.000000119 & 0.00000002 & 0.00000016 & $0.75,1$ \\
\hline$a^{6}$ & 0.1082 & 0.00000000 & 0.000000101 & 0.00000000 & 0.00000002 & $0.75,1$ \\
\hline$a^{7}$ & 0.1081 & 0.00018295 & 0.000000512 & 0.00000339 & 0.00000028 & $0.75,1$ \\
\hline$a^{8}$ & 0.1070 & 0.00009377 & 0.000025696 & 0.00000016 & 0.00000077 & $0.75,1$ \\
\hline$a^{9}$ & 0.1076 & 0.00057695 & 0.000027157 & 0.00005837 & 0.00000054 & $0.75,1$ \\
\hline$a^{10}$ & 0.1035 & 0.00000787 & 0.000024599 & 0.00074929 & 0.05018517 & $0.5,0.75$ \\
\hline$a^{11}$ & 0.1083 & 0.00000000 & 0.000000037 & 0.00000000 & 0.00000001 & $0.75,1$ \\
\hline$a^{12}$ & 0.1055 & 0.00000535 & 0.000002838 & 0.00001344 & 0.00000157 & $0.5,0.75$ \\
\hline$a^{13}$ & 0.0945 & 0.00000056 & 0.000000376 & 0.00000015 & 0.00000013 & $0.75,1$ \\
\hline$a^{14}$ & 0.1077 & 0.00027332 & 0.000003672 & 0.00000056 & 0.00000148 & $0.5,0.75$ \\
\hline$a^{15}$ & 0.0000 & 0.01183859 & 0.001625666 & 0.00090611 & 0.00000467 & $0,0.25$ \\
\hline$a^{16}$ & 0.0990 & 0.00429560 & 0.000189053 & 0.00007410 & 0.00002731 & $0,0.25$ \\
\hline$a^{17}$ & 0.0964 & 0.00642808 & 0.000666838 & 0.00006546 & 0.00001670 & $0.25,0.5$ \\
\hline$a^{18}$ & 0.1076 & 0.00000000 & 0.000010852 & 0.00000005 & 0.00000147 & $0.75,1$ \\
\hline$a^{19}$ & 0.0561 & 0.00672455 & 0.001175007 & 0.00031920 & 0.00000556 & $0.5,0.75$ \\
\hline$a^{20}$ & 0.1040 & 0.00561914 & 0.000137151 & 0.00024912 & 0.00001557 & $0.5,0.75$ \\
\hline$a^{21}$ & 0.1035 & 0.00086162 & 0.000021303 & 0.00000685 & 0.00000221 & $0.5,0.75$ \\
\hline$a^{22}$ & 0.1048 & 0.00070004 & 0.000028486 & 0.00000549 & 0.00000381 & $0.5,0.75$ \\
\hline$a^{23}$ & 0.1078 & 0.00003570 & 0.000007990 & 0.00000794 & 0.00000026 & $0.75,1$ \\
\hline$a^{24}$ & 0.1021 & 0.00000000 & 0.000000000 & 0.00000002 & 0.00000004 & $0.75,1$ \\
\hline$a^{25}$ & 0.0871 & 0.01070003 & 0.001408641 & 0.00080527 & 0.00004083 & $0.25,0.5$ \\
\hline$a^{26}$ & 0.1083 & 0.00000000 & 0.000000000 & 0.00000001 & 0.00000005 & $0.75,1$ \\
\hline$a^{27}$ & 0.1043 & 0.00006081 & 0.000130687 & 0.00004508 & 0.00000557 & $0.25,0.5$ \\
\hline$a^{28}$ & 0.1003 & 0.00171975 & 0.000162787 & 0.00008587 & 0.00000449 & $0.5,0.75$ \\
\hline$a^{29}$ & 0.0950 & 0.00170741 & 0.000186782 & 0.00003183 & 0.00000155 & $0.75,1$ \\
\hline$a^{30}$ & 0.1055 & 0.00000001 & 0.000004628 & 0.00006025 & 0.00006308 & $0.5,0.75$ \\
\hline$a^{31}$ & 0.1054 & 0.00000021 & 0.000007469 & 0.00000089 & 0.00001444 & $0.5,0.75$ \\
\hline$a^{32}$ & 0.0918 & 0.00214265 & 0.000079828 & 0.00000064 & 0.00000059 & $0.5,0.75$ \\
\hline$a^{33}$ & 0.1054 & 0.00025160 & 0.000144627 & 0.00016413 & 0.00000611 & $0.5,0.75$ \\
\hline$a^{34}$ & 0.0845 & 0.00001004 & 0.000022881 & 0.00000000 & 0.00000199 & $0.75,1$ \\
\hline
\end{tabular}


International Journal of Managing Information Technology (IJMIT) Vol.7, No.3, August 2015

\begin{tabular}{|c|r|r|r|r|r|c|}
\hline$a^{35}$ & 0.1072 & 0.00000047 & 0.000035289 & 0.00004086 & 0.00001963 & $0.25,0.5$ \\
\hline$a^{36}$ & 0.1059 & 0.00070839 & 0.000127858 & 0.00001129 & 0.00001205 & $0.5,0.75$ \\
\hline$a^{37}$ & 0.1071 & 0.00001594 & 0.000011810 & 0.00002302 & 0.00001205 & $0.5,0.75$ \\
\hline$a^{38}$ & 0.1073 & 0.00000000 & 0.000021973 & 0.00000016 & 0.00002096 & $0.5,0.75$ \\
\hline$a^{39}$ & 0.1074 & 0.00000111 & 0.000006491 & 0.00000013 & 0.00000298 & $0.75,1$ \\
\hline$a^{40}$ & 0.1080 & 0.00000130 & 0.000002320 & 0.00000327 & 0.00028058 & $0.5,0.75$ \\
\hline$a^{41}$ & 0.1077 & 0.00000000 & 0.000007731 & 0.00000000 & 0.00010914 & $0.75,1$ \\
\hline$a^{42}$ & 0.1083 & 0.00000000 & 0.00000006 & 0.00000001 & 0.00000091 & $0.75,1$ \\
\hline$a^{43}$ & 0.1077 & 0.00006046 & 0.000012616 & 0.00009119 & 0.00018206 & $0.75,1$ \\
\hline$a^{44}$ & 0.1078 & 0.00000017 & 0.000007396 & 0.00002518 & 0.00036302 & $0.5,0.75$ \\
\hline$a^{45}$ & 0.1083 & 0.00000000 & 0.000000034 & 0.00000000 & 0.00001098 & $0.75,1$ \\
\hline$a^{46}$ & 0.1042 & 0.00162244 & 0.000472976 & 0.00013154 & 0.00073699 & $0.25,0.5$ \\
\hline$a^{47}$ & 0.1057 & 0.00017603 & 0.000119918 & 0.00004201 & 0.00008686 & $0,0.25$ \\
\hline$a^{48}$ & 0.1039 & 0.00464383 & 0.000302556 & 0.00110753 & 0.00004129 & $0.25,0.5$ \\
\hline$a^{49}$ & 0.1082 & 0.00000051 & 0.000001002 & 0.00002064 & 0.00053431 & $0.75,1$ \\
\hline$a^{50}$ & 0.1083 & 0.00000000 & 0.00000009 & 0.00000130 & 0.00000230 & $0.75,1$ \\
\hline$a^{+}$ & 0.1083 & 0.0118 & 0.0016 & 0.0012 & 0.0502 & 1 \\
\hline
\end{tabular}

Note: $z \in[x, y]$ " represent " $x \leq z \leq y$ ".

In Table 5, it have shown the analysis of two DEA based methods, the individual optimization models $\left(D\left(a^{i}\right)^{+} \& D\left(a^{i}\right)^{-}\right)$and integrated optimization model $\left(D\left(a^{i}\right)\right)$. Integrated optimization model ranking gives the final ranking of hazardous waste of all states of the USA.

Table 5: Final distance performance and ranking

\begin{tabular}{|c|c|c|c|c|c|c|}
\hline \multirow{2}{*}{ Alternative } & \multicolumn{7}{|c|}{ Criteria } \\
\cline { 2 - 7 } & $D\left(a^{i}\right)^{+}$ & $\begin{array}{c}\text { Ranking } \\
1\end{array}$ & $D\left(a^{i}\right)^{-}$ & $\begin{array}{c}\text { Ranking } \\
2\end{array}$ & $D\left(a^{i}\right)$ & $\begin{array}{c}\text { Ranking } \\
3\end{array}$ \\
\hline$a^{1}$ & 0.254678 & 48 & 0.329047 & 10 & 0.563702 & 42 \\
\hline$a^{2}$ & 0.234953 & 9 & 0.321495 & 40 & 0.577763 & 12 \\
\hline$a^{3}$ & 0.250051 & 33 & 0.328529 & 19 & 0.56782 & 29 \\
\hline$a^{4}$ & 0.250628 & 34 & 0.320246 & 41 & 0.560975 & 45 \\
\hline$a^{5}$ & 0.246416 & 25 & 0.329621 & 5 & 0.572222 & 21 \\
\hline$a^{6}$ & 0.254525 & 45 & 0.328977 & 15 & 0.563797 & 40 \\
\hline$a^{7}$ & 0.248363 & 28 & 0.329126 & 6 & 0.569926 & 23 \\
\hline$a^{8}$ & 0.249102 & 31 & 0.327321 & 27 & 0.567849 & 27 \\
\hline$a^{9}$ & 0.242931 & 21 & 0.329063 & 8 & 0.575291 & 16 \\
\hline$a^{10}$ & 0.112249 & 1 & 0.393064 & 1 & 0.777863 & 1 \\
\hline$a^{11}$ & 0.254565 & 46 & 0.329014 & 13 & 0.563787 & 41 \\
\hline$a^{12}$ & 0.25189 & 38 & 0.324876 & 34 & 0.563271 & 43 \\
\hline
\end{tabular}


International Journal of Managing Information Technology (IJMIT) Vol.7, No.3, August 2015

\begin{tabular}{|c|c|c|c|c|c|c|}
\hline$a^{13}$ & 0.254832 & 49 & 0.307332 & 46 & 0.546694 & 47 \\
\hline$a^{14}$ & 0.246569 & 26 & 0.328585 & 18 & 0.571299 & 22 \\
\hline$a^{15}$ & 0.39689 & 50 & 0.119896 & 50 & 0.232003 & 50 \\
\hline$a^{16}$ & 0.226587 & 7 & 0.32189 & 38 & 0.58688 & 7 \\
\hline$a^{17}$ & 0.224634 & 5 & 0.321815 & 39 & 0.588921 & 6 \\
\hline$a^{18}$ & 0.253071 & 40 & 0.328048 & 22 & 0.564512 & 37 \\
\hline$a^{19}$ & 0.242255 & 20 & 0.253545 & 49 & 0.511386 & 49 \\
\hline$a^{20}$ & 0.225381 & 6 & 0.33162 & 3 & 0.595367 & 4 \\
\hline$a^{21}$ & 0.241254 & 18 & 0.32304 & 37 & 0.572468 & 20 \\
\hline$a^{22}$ & 0.24167 & 19 & 0.324909 & 33 & 0.573457 & 17 \\
\hline$a^{23}$ & 0.250922 & 36 & 0.328435 & 20 & 0.566896 & 32 \\
\hline$a^{24}$ & 0.254669 & 47 & 0.319534 & 43 & 0.556482 & 46 \\
\hline$a^{25}$ & 0.220399 & 3 & 0.316341 & 44 & 0.589375 & 5 \\
\hline$a^{26}$ & 0.254485 & 44 & 0.329072 & 7 & 0.563907 & 39 \\
\hline$a^{27}$ & 0.246974 & 27 & 0.323402 & 36 & 0.566997 & 31 \\
\hline$a^{28}$ & 0.235238 & 10 & 0.319841 & 42 & 0.576208 & 15 \\
\hline$a^{29}$ & 0.237015 & 12 & 0.311412 & 45 & 0.567827 & 28 \\
\hline$a^{30}$ & 0.2464 & 24 & 0.325028 & 32 & 0.5688 & 24 \\
\hline$a^{31}$ & 0.250636 & 35 & 0.324698 & 35 & 0.564365 & 38 \\
\hline$a^{32}$ & 0.237863 & 14 & 0.306616 & 47 & 0.563137 & 44 \\
\hline$a^{33}$ & 0.242943 & 22 & 0.325597 & 31 & 0.572689 & 18 \\
\hline$a^{34}$ & 0.254289 & 43 & 0.29078 & 48 & 0.533473 & 48 \\
\hline$a^{35}$ & 0.248803 & 30 & 0.327499 & 25 & 0.568276 & 25 \\
\hline$a^{36}$ & 0.239258 & 17 & 0.326698 & 29 & 0.57725 & 14 \\
\hline$a^{37}$ & 0.248785 & 29 & 0.327304 & 28 & 0.568149 & 26 \\
\hline$a^{38}$ & 0.249908 & 32 & 0.327594 & 24 & 0.567261 & 30 \\
\hline$a^{39}$ & 0.25228 & 39 & 0.327804 & 23 & 0.565098 & 35 \\
\hline$a^{40}$ & 0.239065 & 16 & 0.329012 & 14 & 0.579169 & 11 \\
\hline$a^{41}$ & 0.245103 & 23 & 0.32837 & 21 & 0.572599 & 19 \\
\hline$a^{42}$ & 0.253824 & 42 & 0.329049 & 9 & 0.56453 & 36 \\
\hline$a^{43}$ & 0.237736 & 13 & 0.328699 & 17 & 0.580294 & 10 \\
\hline$a^{44}$ & 0.236783 & 11 & 0.328928 & 16 & 0.581441 & 9 \\
\hline$a^{45}$ & 0.251749 & 37 & 0.329034 & 12 & 0.566535 & 33 \\
\hline$a^{46}$ & 0.21067 & 2 & 0.327411 & 26 & 0.608479 & 2 \\
\hline$a^{47}$ & 0.238547 & 15 & 0.325839 & 30 & 0.577334 & 13 \\
\hline$a^{48}$ & 0.222607 & 4 & 0.331665 & 2 & 0.598379 & 3 \\
\hline$a^{49}$ & 0.233479 & 8 & 0.329764 & 4 & 0.585474 & 8 \\
\hline$a^{50}$ & 0.253184 & 41 & 0.329046 & 11 & 0.565148 & 34 \\
\hline
\end{tabular}


International Journal of Managing Information Technology (IJMIT) Vol.7, No.3, August 2015

\section{RESULT AND CONCLUSION}

The final result has been shown in Table 5 (Final distance performance and ranking), which revels DEA based methods. As the ranking result from Table 5, generated from the integrated optimization model (ranking 3) consider both distance from idea and anti-idea values. It is also suggested that one of these two ranking should be selected for further findings. From our analysis, we found that Washington is ranked $1^{\text {st }}$ in well managed hazardous waste even after its population density $\left(\mathrm{C}_{5}^{\mathrm{c}}\right)\left(9856.5\right.$ per $\left.\mathrm{km}^{2}\right)$ is much higher than that of the other states. Washington is well organized in hazardous waste in comparison to the other states. Similarly, Texas is ranked $50^{\text {th }}$ which is last in overall states of the USA. Texas population density is 96.3 per $\mathrm{km}^{2}$ and waste generation is 15683408 , which is maximum hazardous waste generated in comparing to population density as well as hazardous waste generation. With respect to generated hazardous waste it hasn't been well managed, so Texas is ranked last in overall states. From our result and ranking of each states of the USA, we believed that if EPA and other respective authority related with hazardous waste management follows the similar process ranked $1^{\text {st }}$ or $2^{\text {nd }}$ or $3^{\text {rd }}$ states then the hazardous waste manage will be more proper and sustainable. It is also suggested that to have mutual understanding between all staff and hazardous waste management authority, so that they can know merits as well as demerits and better ways for managed hazardous waste.

In this study, our analysis indicated that the prioritization of the all fifty states of the USA is ranked in Table 5 and level based on the ranking result from the integrated model. This ranking result could be served as the decision making for the EPA (Environmental Protection Agency) to improve hazardous waste in the other states which is not well managed. Hybrid approach of DEA-TOPSIS is used for analysis to capitalize the unique features from both methods for improving multiple criteria decision analysis. This study uses the data available from RTKNet, which data were provided by EPA to know the hazardous waste situation in the USA. The result from both individual optimization models and integrated optimization models, entailing the hazardous waste in the USA by ranking each states according to hazardous waste managed. This result will also help EPA and government to make decision related to finance as to manage hazardous waste as well as make policies for future.

\section{REFERENCES}

[1] Chen. Y, Kevin W. Li, Haiyan XU, Sifeng LIU (2009). A DEA-TOPSIS method for multiple criteria decision analysis in emergency management. J SystSciSystEng, paper: 1861-9576.

[2] Chen, Y., Su, X. \&Hipel, K.W. (2009). An index aggregation approach to comparing the overall performance of emerging and developed countries. Socio-Economic Planning Sciences, 43: 25-39

[3] Chen, Y., Kilgour, D.M. \&Hipel, K.W. (2006). Multiple criteria classification with an application in water resources planning. Computers and Operations Research, 33: 3301-3323Deng H, Yeh C -H, Willis RJ (2000) Inter-company comparison using $\mathrm{m}$ odified TOPSIS with objective weights. ComputOper Res 27(10):963-973

[4] Chen M-F, Tzeng G-H (2004) Combining grey relation and TOPSIS concepts for selecting an expatriate host country. Math Comput Mode 1140 : 1473 - 1490

[5] Chui, E. (2003). Unmasking the "Naturalness" of "Community Eclipse'”: The case of Hong Kong. Community Development Journal, 38, $151-163$.

[6] Chu TC ( 2002) Facility location selection u sing fuzzy TOPSIS under g roup decision. Int J Uncertain Fuzz Knowl B asedSyst 10(6):687-701 
[7] Chu, Mei-Tai, Shyu, Joseph, Tzeng, Gwo-Hshiung, \& Khosla, Rajiv (2007). Comparison among three analytical methods for knowledge communities' group-decision analysis. Expert Systems with Applications, 33, 1011-1024.

[8] Cook, W. \& Kress, M. (1994). A multiple-criterion composite index model for quantitative and qualitative data. European Journal of Operational Research, 78: 367-379

[9] Emrouznejad, A., Parker, B.R. \& Tavares, G. (2008). Evaluation of research in efficiency and productivity: a survey and analysis of the first 30 years of scholarly literature in DEA. SocioEconomic Planning Sciences, 42: 151-157

[10] Figueira, J., Greco, S. \&Ehrgott, M. (2005). Multiple Criteria Decision Analysis: State of the Art Surveys. Springer, New York.

[11] Figueira, J., Greco, S. \&Ehrgott, M. (2005). Multiple Criteria Decision Analysis: State of the Art Surveys. Springer, New York.

[12] Fung, B. C. K. (2001). Planning for high-density development in Hong Kong. Planning Department, Hong Kong.

[13] Hwang C L, Yoon KP (1981) Multiple attribute decision making methods and applications: a state-ofthe-art survey New York. Springer, Berlin.

[14] Janic M (2003) Multicriteria evaluation o $\mathrm{f} \mathrm{h}$ igh-speed rail, transrapid maglev and air passenger transport in Europe. Trans Plan Technol 26(6):491-512

[15] Keeney, R.L. \&Raiffa, H. (1976). Decisions with Multiple Objectives: Preferences and Value Tradeoffs. Wiley, New York.

[16] Lin M-C, Wang C -C, C hen M-S, C hang CA (2008a) Using AHP and TOPSIS approaches in customerdriven product $\mathrm{d}$ esign $\mathrm{p}$ rocess. Comput Indus 59(1):17-31

[17 ]in Y-H, Lee P-C, Chang TP, Ting H-I ( 2008b) Multi-attribute g roup decision making model under the condition of uncertain information. Automat $C$ onstruct 17(6):792-797

[18] Lin H-T, C hang W- L ( 2008) Order selection and pricing methods using flex ible quantity and f uzzy approach for buyer evaluation . Eur JO per Res 187 (2) : $415-428$

[19] Ng, M. K., Cook, A., Chui, E. W. T. (2001). The road not travelled: A sustainable urban regeneration strategy for Hong Kong. Planning Practice and Research, 16, $171-183$.

[20] Ramanathan, R. (2006). Data envelopment analysis for weight derivation and aggregation in the analytic hierarchy process. Computers and Operations Research, 33: 1289-1307

[21] Roy, B. (1996). Multicriteria Methodology for Decision Aiding. Kluwer, Dordrecht.

[22] Saaty, T.L. (1980). Analytic Hierarchy Process. McGraw Hill, New York.

[23] Seydel, J. (2006). Data envelopment analysis for decision support. Industrial Management \& Data Systems, 106: 81-95

[24] Shih H-S, Shyur H-J, Lee ES (2007). An ex tension of TOPSIS f or group decision m aking. Math Comput Mode $1145(7-8): 801-813$

[25] Stewart, T. (1996). Relationships between data envelopment analysis and multicriteria decision analysis. Journal of the Operational Research Society, 47: 654-665

[26] Tsaur S-H, C hang T- Y, Yen C -H (2002) The evaluation of airline service quality by fuzzy MCDM. Tour $\mathrm{M}$ a n a ge 23 ( 2): $107-115$

[27] Tsou, C.-S. (2007). Multi-objective inventory planning using MOPSO and TOPSIS. Expert Systems with Applications. doi:10.1016/j.eswa.2007. 06.009

[28] Wang, Y.M. \& Chin, K.S. (2009). A new data envelopment analysis method for priority determination and group decision making in the analytic hierarchy process. European Journal of Operational Research, 195: 239-250

[29] Wang, Tien-Chin, \& Chang, Tsung-Han (2007). Application of TOPSIS in evaluating initial training aircraft under a fuzzy environment. Expert Systems with Applications, 33(4), 870-880.

[30] Yurdakul, M., \& IC, Y. T. (2005). Development of a performance measurement model for manufacturing companies using the AHP and TOPSIS approaches. International Journal of Production Research, 43(21), 4609-4641. 